Zagadnienia Rodzajów Literackich, LX, z. 3

PL ISSN 0084-4446

DOI: $10.26485 / Z R L / 2017 / 60.3 / 6$

Anna Wendorf

Uniwersytet Łódzki*

\title{
Audio Description in Fine Arts
}

\begin{abstract}
This article is about audio description of works of art. The term audio description is defined at the beginning of the text, next there is a description of how AD began in the United States and in Poland. After that, the types of AD in works of art and the rules of its creating are presented. The following paragraphs are about translating paintings through the senses, that is the hearing (ekphrasis, soundpainting), the touch (miniature models, typhlographies, touch tours) the smell or the taste (specially prepared fragrance or taste composition). The article finishes with the author looking at AD in plastic arts in Muzeum Sztuki in Łódź and the Museum of the City of Lódź.
\end{abstract}


* Zakład Literatur Hiszpańskojęzycznych, Katedra Filologii Hiszpańskiej Uniwersytet Lódzki

ul. Pomorska 171/173, 90-236 Łódź

e-mail: anna.wendorff@uni.lodz.pl 


\section{Introduction}

One of the challenges for humanists today is promoting equal access to culture for everyone, and this means including the disabled in social and cultural life by creating conditions in which they can access cultural heritage. One of the phenomena connected with facilitating such access to the broadly accepted notion of art for the visually impaired is audio description, which enables the blind and the visually impaired to experience the visible cultural heritage of fine arts, theatre and the performing arts, or film. Our article will reflect upon the audio description of works of art.

\section{Definition}

Audio description (AD) is a verbal and audio summary of the image and the visual content which facilitates an independent and competent reception of the art form. AD falls under intersemiotic translation, since it is a translation of one sign system into another; it thus translates a message encoded within one system into a message within another; it interprets a non-verbal sign by means of a verbal one, a non-linguistic message through linguistic means (Díaz Cintas 2007: 9-23). Therefore, a fine art audio description translates a message encoded in one system, e.g. a painting, into another, e.g. a verbal description; visual signs into verbal ones. AD is of interest to audio visual translators and poses challenges within present day translation studies.

Audio description in its conception was designed with the visually impaired in mind, that is, those who were born blind, those who suffered eyesight loss at some point in their lives and people who are near-blind. However, it must be noted that AD can be of use to the elderly, people with other impairments e.g. with an intellectual disability, or visitors with a limited understanding of the host language who want to facilitate and/or deepen their comprehension of certain content. Visual description is thus a form of communication, since it is translation into a language that is comprehensible to a wider audience. In this way, the ideals of integration and inclusion are fulfilled. 


\section{The beginnings of audio description in fine arts}

Audio description in fine arts was initiated in 1986 in the United States. The Metropolitan Washington Ear created the first audio descriptions on cassettes for two New York attractions run by The National Park Service: The Statue of Liberty and Castle Clinton.

In Poland, Foundation for Children Help on Time [Fundacja Dzieciom Zdażyć z Pomoca] ran a project called Beyond Silence and Darkness [Poza Cisqq i Ciemnościa] from 2008 to 2012, which has been continued by the Culture without Borders Foundation [Fundacja Kultury Bez Barier] since 2013. The project aims to include disenfranchised members of society into cultural and social life and has already (until 2017) produced audio descriptions for four museums: the Warsaw Rising Museum [Muzeum Powstania Warszawskiego], the Museum of the Royal Castle in Warsaw [Muzeum Zamku Królewskiego w Warszawie] (for four chambers: The Throne Room, the Marble Room, the Knights' Hall, the royal Bedchamber), the National Museum in Warsaw [Muzeum Narodowe w Warszawie] (for 40 works of art within the exhibition in the Rabbit House [Królikarnia]), and the Fryderyk Chopin Museum [Muzeum Fryderyka Chopina]. It is worth mentioning the fact that in 2011 this project was awarded a City Dwellers' Award [Nagroda Mieszkańców] in the S3CTIONS 2010 [S3KTORY 2010] competition — that is, an award for the best non-governmental undertaking in Warsaw. In 2009, a retrospective exhibition called my whole body trembles when I can lavish gold upon you [drie więc cały, gdy moge was ozłocic] by Marek Kijowski was organised in the Arsenal Gallery (Galeria Arsenał) in Białystok, while an audio guide with audio descriptive commentary was created for the Museum of Nature (Muzeum Przyrody) in Drozdowo within a project called We facilitate access to our museum for the visually impaired and foreign speakers [Udostepniamy Muzeum gościom niewidzacym i obcojezycznym]. In 2010, Wrocław-based Panorama of the Battle of Raclawice [Panorama Raclawicka] by Jan Styka and Wojciech Kossak gained an audio description, and the first video-art with an audio description commentary, entitled Cheerful Spirit [Pogoda Ducha], was presented by Jakub Jasiukiewicz in the Malt House [Słodownia] in Poznań. The year 2011 saw the first radio broadcast with audio description aired by Białystok Polish Radio — it was a series of radio programmes that presented the most precious and interesting works of plastic arts from various epochs.

\section{Types of $\mathrm{AD}$ in the fine arts}

A simple division of audio description in museums might be into audio files recorded and presented as audio-guides (often made available on the museum's website), or it may be created live at the time of visiting e.g. read out (Więckowski 2013: 78-79). The Report on user needs assessment from 2012 (Audio Description: Lifelong Access for the Blind 2012: 29) features a more detailed division of $\mathrm{AD}$ with regard to the aim and mode of presentation, the target group and the type of text. The first category comprises instructive AD (an instruction manual), functional AD (information about the building and room location), directional AD (how to move about in the building), information AD (about exhibits), tactile (information on how to touch exhibits), and hybrid AD (a combination of the above-mentioned types). As for the mode, $\mathrm{AD}$ is divided into live $\mathrm{AD}$ (with or without script) and recorded AD (accessed through an audio-guide, multimedia guide or an iPod, usually a hybrid AD). In the target group category, there is standard AD (for the visually 
impaired) or integrated AD (as part of the audio-guide for everybody). The type of text category features: description, narration, commentary, a dialogue or a combination of these types.

\section{Rules for $\mathrm{AD}$ creation in fine arts}

With regard to AD standards in Poland, it is the non-governmental organisations that play a vital role, among others the Audio Description Foundation [Fundacja Audiodeskrypcja] and the Culture without Borders Foundation [Fundacja Kultury bez Barier].

The Audio Description Foundation [Fundacja Audiodeskrypcja] was the first Polish NGO to become involved in providing audio description. Marta Golik-Gryglas, who cooperates with this foundation, takes a closer look at the rules for AD creation in fine arts in her article entitled Audio Description in Visual Arts [Audiodeskrypcja w sztukach plastycznych] (Golik-Gryglas n.d.). In the author's opinion, visual description should begin with the most basic information on the work of art, that is, culture area, artistic school or the author, the title, dimensions and the place where it is housed or its owner; then, information on composition, shapes, theme, colours, and chiaroscuro should follow. The description should follow from a general notion to a detailed one. Golik-Gryglas remarks that 'at this stage the listener should have a very general and vague picture, which — as more details come together - will assume specific shape, show its detailed complexity, colours and subtleties' (Golik-Gryglas n.d.: n.p.). The author proposes that the language used in such descriptions be succinct, precise, direct and objective, the sentences short and simple, and comparisons used cautiously. She stresses that the description should only include what can be seen, so as to leave the listener room for their own interpretation and opinion. The author suggests that the description should finish with information on the artwork's history, e.g. artistic style or technique, historic details about the exhibit, details about its founders, iconographic details, artistic context or some anecdotes and trivia connected with the artist or the work's creation process (Golik-Gryglas n.d.: n.p.).

The Culture without Borders Foundation [Fundacja Kultury bez Barier] has published on its website the following indices on audio description:

As for works of art, architectural monuments, exhibitions and museum exhibits, nature trails, etc., audio descriptor should not only take a careful look at the object of the description, but also gain factual information (theory, history, artistic technique, the artist or creator's idea behind the exhibition, interpretation, anecdotes, etc.) (...) In certain justified cases, we do not describe in a general way but explain and present the cultural code, symbol or formal device embedded in the work of art and expressed in its content. It is commonly used in fine arts and other stationary objects, especially when the descriptor's task is to prepare a guide book for the blind which combines factual knowledge and description (Fundacja Kultury bez Barier 2012: 2-3).

In their document Audio Description - Principles of Creation [Audiodeskrypcja — zasady tworzenia] (2012), Izabela Künstler, Urszula Butkiewicz and Robert Więckowski also mention that stationary objects, such as paintings, do not pose a time limitation on the audio descriptor - as they do not have to synchronise the audio description with the soundtrack or performance, like in film or theatre. However, the descriptor is limited by the perception span of the target listener, so they need to control the flow of information. 
It is recommended to limit the description to three or four perspectives, and to use accurate, meaningful vocabulary, comparisons, epithets and metaphors, as well as colours and spatial relationships in order to stimulate the listener's imagination. Another guideline is that the audio descriptor should strive to be objective, avoiding their own comments or opinions, and deliver a description stylistically coherent with the work of art (Fundacja Kultury bez Barier 2012: 3-6).

Among Polish publications on audio description, the works of Robert Więckowski are especially noteworthy. In his article Audio Description of Beauty [Audiodeskrypcja piekna] (Więckowski 2014: 109-123) Więckowski analyses the accuracy between the work of art and its audio description (2014: 112), that is, between the source text and target text, which touches on the eternal issue of accuracy and faithfulness to the original in translation. Więckowski rightly points out that, as opposed to $\mathrm{AD}$ in other visual forms or art (theatre or film e.g. dialogues, music), $\mathrm{AD}$ in fine arts does not need an alternative soundtrack, therefore the listener perceives the artwork only through the audio description. Thus, accuracy in this type of translation gains special importance (2014: 114).

The author also states that the five types of description proposed by Janusz Sławiński for the purpose of literary studies can successfully be used for audio description (2014: 117-118). These are as follows: anarchistic (without any rules, allowing freedom and omissions), with a unifying frame (at the beginning and at the end there is a frame device that explains the choice of narration and unifies various elements), with a semantic dominant (enumeration governed by a specific semantic dominant, usually a metaphor or an elaborate comparison), kinetic (showing a person/object in movement or in the process of becoming), transform space (it is an elaborate version of the kinetic description where not only is the object animated, but also the whole space, which changes and undergoes transformations). Not without reason, audio description is also called narrative description, verbal description or video description.

It is worth noting that, since 2013, Więckowski, together with Wojciech Figiel, and in cooperation with the Culture without Borders Foundation [Fundacja Kultury bez Barier] and the Audio Visual Translation Laboratory [Laboratorium Przekładu Audiowizualnego] (AVT Lab), has been conducting extensive research in the quality analysis of audio description in fine arts, which will undoubtedly contribute to the creation of a verbal description better suited to the needs of the visually impaired.

\section{Image translation through other senses}

Audio description should have a similar influence on its recipient — both in quality and duration — to the impact that a painting has on a person without eyesight disabilities' (Dworak 2015: 2). This objective is fulfilled by verbal elements, as well as sound, music and touch, thanks to the use of multisensory solutions. Neves highlights that works of fine art rely on creative ambiguity which is difficult to render through just verbal means (Neves 2012: 289), which makes AD in fine arts creations a gentle departure from the general requirement of objectivity and in this type of $\mathrm{AD}$ descriptions can be more subjective and creative than for other works of art.

Audio description, as its name suggests, is a verbal and audio summary, hence it requires hearing. This sense can further be stimulated by the use of ekphrasis, for example. This device was used in the narrative poems of Ancient Greece and was initially passed 
down orally, which is not insignificant, since visual description is an oral form, too (Pujol and Otero 2007: 49). Ekphrasis used to be simply a live description, but since the 19th century it has been connected with the describing paintings (2007: 50). Ekphrasis renders a painting with words; a rendition that may even substitute for the original. Some literary scholars consider ekphrasis to be a literary genre in its own right 'a poem that constitutes a description of a painting, sculpture or building' (Sławiński 1998: 122), some as a figure of speech, yet others suggest that the term 'the phenomenon of ekphrasis' is more appropriate than ekphrasis alone (Dziadek 2004: 55-56).

Let us now consider two important characterizations of ekphrasis authored by Hermogenes and Quintilian, which, beyond doubt, are connected with audio description. Hermogenes says that 'the special virtues of ekphrasis are clarity and visibility; the style should contrive to bring about seeing through hearing' (Hermogenes, Progymnasmata, 10, trans. Elsner 1995, cited in: Pujol and Otero 2007: 51), whereas Quintilian highlights that ekphrases 'recreate in our spirit the image of things that are not present' (Quintilian, VII, II, 29, 1985, as cited in: Pujol and Otero 2007: 51). Pujol and Otero point to the fact that ekphrasis allows us to create our own internal visual representation, thanks to the evocative abilities of the language, visualising the power of the word, which makes it possible to reveal what is beyond language and directly experienced. They also point to the narrative potential of a picture and the potential for ekphrasis to evoke feelings and emotion qualities pertinent to art (Pujol and Otero 2007: 51-53).

In his article Audio Description of Beauty [Audiodeskrypcja piekena], Więckowski also highlights the role of ekphrasis in AD, justifying his stance that, since literature has ekphrases - rhetoric devices which are live descriptions of a work of art, and which aim to evoke the same vision in the listener or reader's mind, that is, descriptions of plastic works of art which are accurate and full of expression; similarly, there should be verbal descriptions for the visually impaired. He also proposes that language malleability should be exploited in AD descriptions through the use of rhetorical terms, most importantly metaphors, thanks to which - as the author says - aesthetic impression and tension can be created in the listener, stimulating their imagination (Więckowski 2014: 120-121).

'The comparison between audio description and ekphrasis shows how subjective and intrinsically artistic the latter is, and — at the same time — how the borderline between the two is fluid' (Kalbarczyk and Mirowski 2015: 109).

Let us now turn to the use of sound in AD. The outstanding device here is soundpainting, understood by Josélia Neves as the sound of words - a new artistic form, which refers to the notion of word painting, tone painting or text painting, that is a music technique that represents the meaning of a song literally in such a way that music tries to emulate the emotions, actions and sounds in the text. Analogically, what Neves means is translating picture through sound, creating a verbal poetic AD enriched with sound effects and music (Neves 2012: 289). It is worth mentioning that Neves considers soundpainting to be creative transcreation.

Transcreation means recreating a text for the target audience: 'translating' and 'recreating' the text; hence the term 'transcreation'. Transcreation is used to make sure the target copy is the same as the source copy in every aspect: the message it conveys, the tone of voice, the images and emotions it evokes and the cultural background. You could say that transcreation is to translation what copywriting is to writing. (Balemans 2013: 122) 
Let us observe that the term transcreation is often used in the context of marketing and advertisement. As the above definitions suggests, the term cannot be likened to translation; it is a stage between translation and copywriting.

It is now time to move to the use of touch in $\mathrm{AD}$. On the one hand, there are miniature models - scaled down 3D constructions of a building or a statue made of wood, plywood, plaster, cardboard, etc. On the other, we have typhlographies - reproductions of works or art which have varied texture and allow us to get to know their composition by touching; special embossed boards, with various surfaces - in a word, tactile versions of paintings, photographs, etc., which are especially useful to describe two dimensional objects in 3D. The last category comprises the so-called touch tours - a tactile experience of exhibits through the use of special gloves.

Visitors to a museum listen to tactile audio description which encourages them to touch va-
rious parts of exhibit models. For example, first they touch the frame of the painting model
to imagine the dimensions and proportions. Next, AD concentrates on a specific point (for
example, the face of the person portrayed) which becomes a point of reference for further
description. (Kalbarczyk and Mirowski 2015: 110)

As for the use of smell in AD, we should notice how certain exhibits have a specially prepared scent composition e.g. of flowers, spruce forest or bonfire wood, which relates directly to the exhibit.

Taste is used in $\mathrm{AD}$ for paintings directly connected with this sense e.g. the exhibit stand may additionally feature a table with the fresh fruit and vegetables depicted in the painting, whose taste completes the sensation gained from the verbal AD.

It should not escape notice that multisensory exhibitions are often accompanied by workshops which use the sensory experience gained from the 'viewing' and relate it to the works of art 'seen' earlier, and whose function is to recycle the experience of the exhibition. During these workshops, objects of varied textures and odours are used to stimulate the sense of touch, hearing or smell.

To sum up this part, it should be stressed that in $\mathrm{AD}$ the word is of utmost importance and cannot be omitted, while all the senses only serve to make it stronger, clearer and richer.

\section{Audio description in fine arts — Łódź}

Let us examine audio description in two Lódź museums: the Art Museum [Muzeum Sztuki] in Lódź and the Museum of the City of Lodz [Muzeum Miasta Lodzi].

Since January 2017, the Art Museum [Muzeum Sztuki] has been carrying out a project called New System to Access the Cultural Offer of the Art Museum in Lódź. [Nowoczesny system dostepu do oferty Muzeum Sztuki w Lodzi] within the Regional Operational Programme for the Voivodeship of Lódź 2014-2020, which aims to create a platform which, among other things, will guarantee safe and obstacle free access to contemporary art, easier access to the museum's resources, as well as limit so-called 'digital exclusion' (Muzeum Sztuki w Lodzi). The project is scheduled to finish in December 2017.

The Art Museum [Muzeum Sztuki] in Łódź has three branches: ms1, ms2 and Herbst Palace Museum [Muzeum Pałac Herbsta]. Ms1, in the former Maurycy Poznański’s Palace at Więckowskiego Street 36, carried out an audio description project including a general description of its Neoplastic Room and four works in this room, that is: Counter-composition 
[Kontrkomposycja] by Theo van Doesburg (1925), Unistic Composition 11 [Komposycja unistyczna 11] by Władysław Strzemiński (1932), Composition of Three Equivalents [Kompozycja trzech równoważnikóm] by Georges Vantongerloo (1921) and Abstract Painting II [Obraz abstrakcyjny II] by Henryk Stażewski (1928-1929). Here is a general description of Unistic Composition 11 [Kompozycja unistyczna 11] by Strzemiński: 'A rectangle composition of a plaited texture resembling that of wicker handicraft. It is pink, violet, green, brown and yellow in colour' (Audiodeskrypcja Sali Neoplastycznej w Muzeum Sztuki w Lodzi 2014: 6). The audio description of each of the above-mentioned works of art was prepared according to the following plan: name of the painting, author, year, technique, dimensions, collection to which the painting belongs, biographical profile and historical background; followed by a general and detailed description. The audio descriptions were prepared by Prof. Aneta Pawłowska from the Art History Department of the University of Lódź together with her students in the academic year 2013-2014 as part of the Audio description of works of art [Audiodeskrypcja diziet sztuki] course. They were advised by Barbara Szymańska from the Audio Description Foundation [Fundacja Audiodeskrypcja]. Unfortunately, these descriptions were only recorded in typewritten form and were not published on the museum's website or made available through multimedia guidebooks or audio guides, which — without doubt — would have facilitated the inclusion of visually impaired people into the social and cultural life of Lódź.

Every year in April, since 2012, both ms1 and ms2 have participated in a museum event called Free Art Day [Džień wolnej sqtuki], at which all Polish museums display five chosen exhibits. With the idea of conscious familiarization with art; without specialist knowledge or prior preparation, the event forms part of the Slow Art Movement. During the event meetings, museum visitors and educators establish an inspiring dialogue about the works of art. The museum always prepares audio descriptions for these five works of art, which are then read out during the meetings to the visually impaired in order to facilitate their cultural and social integration.

Ms2, which houses a 20th and 21st century art collection, ran a project, Encouragement Workshop II [Warsztat na Zachete II], which was subsidised by the Ministry of Culture and National Heritage. The project's goal was to make contemporary art more accessible to people with sensory disabilities. For people with visual impairment, the Culture without Borders Foundation [Fundacja Kultury bez Barier] prepared, in 2014, an audio description and typhlography of Unistic Work No. 14 [Praca unistyczna nr 14] by Władysław Strzemiński. Workshops within Encouragement Workshop [Warsztat na zachęte] for this painting and Strzemiński's artworks in general was jointly presented by Leszek Karczewski and Katarzyna Mądrzycka-Adamczyk, both employees of the museum's education department. After the presenters introduced themselves and the topic, the audio description of one work of art from Unistic Compositions [Komposycje unistyczne] was read out. Below, there is a very vivid, evocative and verbally plastic fragment from the said series of paintings:

The work is bright, greyish blue all over. It is covered with tiny contour elements. Spaces in between are small. There are elements of the size of the big toe nail in the central section. Their shape is almost square. The further from the centre, the smaller and rounder the shapes become. The smallest are close to the edge, the size of a tiny little finger. They are retrieved from the background only through the use of thick impasto. The elements near the frame are in almost neat rows. In the middle, the rows become sparser. (Warsztat na Zachętę II — Lódź. Muzeum Sztuki w Lodzi 2014) 
It should not escape notice that the described painting is described through its colours and shades (greyish blue, bright), shapes (square, round) and comparisons to familiar sizes ('the size of the big toe nail', 'the size of a tiny little finger'). Let us mention that after the audio description was read out, the visitors were presented with the typhlography of the painting and took part in workshops with jigsaw puzzles, string, buckwheat and jelly dessert, all of which helped to bring to life the painting and the artist's views on art through play and integration.

Within this project there was also another workshop devoted to Jadwiga Sawicka — an artist whose art relies heavily on clothing — and entitled What Does Art Wear? [W co ubiera sie sztuka?. The participants were able to touch a typhlography and listen to an audio description of one of her works: a bathing suit from 1999, and also express their own emotions by creating a joint installation from clothes.

Visual descriptions were made of certain other paintings from ms 2 museum, created by art history students guided by Prof. Pawłowska in the years 2014-2015 as part of their professional degree project, however, these have not been made public.

In 2013, Herbst Palace Museum, located at Przędzalniana Street 72 in Lódź, was equipped with an innovative and extensive system called Whispers [Podszepty], which combines audio description with other technical aspects. AD commentaries are triggered automatically when a visitor passes a place or exhibit, thanks to sensors placed around the museum: in the palace, in the garden and in the Gallery of Old Art [Galeria Sztuki Dawnej] (the system will no longer include this particular zone from 10th June 2016 to 15th October 2017 due to a change in the exhibition), thanks to which visually challenged visitors can safely and independently visit this art museum branch.

The tour starts when visually impaired visitors collect an audio guide and a special transmitter and then attach it either to their cane or themselves. The visitor is then instructed how to operate the device - allowing them to experience the instructive audio description and thereby obtain information on the buildings of the palace and the rooms as well as how to move about (functional and direction AD) - and is also informative when the very rooms and paintings are described to them. An AD fragment of one palace painting, Sęriwój, the Alchemist [Alchemik Sęriwój] by Jan Matejko, is presented here: 'Almost everybody in the painting is staring at one point. They are stooping, leaning out to better see an object in the bright light coming from the fireplace' (Audiodeskrypcja obrazu Alchemik Sędriwój Jana Matejki). This vivid description undoubtedly shows how the following devices are used: literary descriptions, ekphrasis, soundpainting or movement, advocated, among others, by Więckowski or Naves. The descriptor here made great use of the evocative function of language; the power of words to conjure images and the narrative potential of an image.

The system received a warm welcome from the blind and the visually impaired community as a whole, and, in 2013, a Sybilla (the most important award that the Ministry of Culture and National Heritage can award a museum) in the digitisation and new technologies category.

Since 7th August 2016, the Herbst Museum Palace [Muzeum Pałac Herbsta], together with Chance for the Blind Foundation [Fundacja Szansa dla Niewidomych], has also been carrying out a project called Training Ground for Experiences [Poligon doswiadczen], which began with an event in the museum's garden, during which traditional audio descriptions were 
presented and the visitors' performative potential was activated — as they became 'live paintings', enacting scenes from the works of art. The project also featured workshops for the blind and visually impaired, and, on 9th September 2016, a national conference took place called Training Ground for Experiences. Art Made Accessible to the Visually Impaired [Poligon doświadczalny. Sztuka dostępna dla osób z dysfunk.cja wrroku].

In the series The Herbst Palace in several versions [Pałac Herbsta w kilku odstonach], the Museum organises proprietary educational workshops, presented by Katarzyna Kończal, during which blind and visually impaired visitors experience the palace rooms through the use of multisensory technology, which activate the senses of hearing and smell (Needle in a Haystack [Igla w stogu siana] workshop), touch (Please, Come into the Living Room [Zapraszamy do salonu]) and movement (While Dancing [Tanecznym krokiem]).

The Museum of the City of Lodz [Muzeum Miasta Lodzi] — which is located in the Poznański Palace at Ogrodowa Street 15 - has been running a project called Museum at Your Fingertips [Muzeum na wyciagniecie rekei] since 2015 within the Accessible Culture [Kultura dostepna] programme organised by the Ministry of Culture and National Heritage, which aims to adapt the museum to the needs of the disabled. As for the blind and the visually impaired specifically, they may use the audio description of all museum rooms and audio guides which include interesting factual details about the museum. Below is a fragment of an AD from one of the palace rooms — the study of Izrael Poznański:

You are in Izrael Poznański's study. It is a rectangular room about 7 by 5 metres. The room is a bit more than 4 metres high - just like most other rooms. The walls are dark brown. A decorative pattern one shade darker was painted on the walls. The only window in the room is on the wall on the right and it's partially covered by heavy plush curtains. The ceiling is covered with brown and gold moulding. There is a richly ornamented circle in the middle of it. In the middle of the circle, there is a massive chandelier which adds enough light. There is a mosaic parquet under your feet. There is a patterned carpet in its centre. (Gabinet Izraela Poznańskiego)

You can read/listen to the texts and recordings of the audio description and audio guides on the museum's website, download them onto your phone or tablet (dostepne.muzeumlodz.pl) or you can borrow special devices in the museum which enable you to listen to them. Before the visit, the visually disabled may also borrow a museum guide in transparent print, that is, enlarged print together with Braille print, Braille maps and typhlographies, and also gloves through which they can touch certain exhibits. The museum also organises sightseeing tours, meetings and workshops for the visually impaired (Muzeum Miasta Lodzi. Udogodnienia).

\section{Conclusions}

One final remark, audio description is a live creation, developing and changing over time; according to the needs of the visually disabled, the development of audio description research or new technologies. We, thus, advocate broadening transdisciplinary audio description studies in the scope of experiencing art through multiple senses, with special regard for sensory compensation, and more technologically advanced mediation between the visual sensations and the haptic, kinesthetic or olfactory sensations. 


\section{Bibliography}

Audio Description: Lifelong Access for the Blind (2012), Report on user needs assessment, n.p. Audiodeskrypcja obrazu Alchemik Sędziwój Jana Matejki (n.d.), Pałac Herbsta, www. palac-herbsta. org.pl/strona-99-warsztaty_dla_osob_z_dysfunkcja_wzroku.html [access: 9.02.2017].

Audiodeskrypcja Sali Neoplastycznej w Muzeum Sztuki w Lodżi (2014), typescript, Katedra Historii Sztuki, Lódź.

Balemans Percy (2013), Transcreation [in:] Diversification in the Language Industry: Success beyond translation, ed. N.Y. Adams, NYA Communications, Brisbane.

Díaz Cintas Jorge (2007), Traducción Audiovisual y Accesibilidad [in:] Traducción y accesibilidad. Subtitulación para sordos y audiodescripción para ciegos: nuevas modalidades de Traducción Audiovisual, ed. C. Jiménez Hurtado, Peter Lang, Frankfurt.

Dworak Jan (2015), Stanowisko Krajowej Rady Radiofonii i Telewizji z dnia 7 lipca 2015 roku w sprawie sposobu realizacji i jakości audiodeskrypcji w utworach audiowizualnych, n.p.

Dziadek Adam (2004), Obrazy i wiersze: z zagadnień interferencij sz̨uk w polskiej poezji wspótczesnej, Wydawnictwo Uniwersytetu Śląskiego, Katowice.

Fundacja Kultury bez Barier (2012), Audiodeskrypcja — zasady tworzenia, http://kulturabezbarier.org/container/Publikacja/Audiodeskrypcja\%20-\%20zasady\%20tworzenia.pdf [access: 8 February 2017].

Gabinet Irraela Poznańskiego, http://dostepne.muzeum-lodz.pl/index.php/materialy-do-pobrania [access: 7 February 2017].

Golik-Gryglas Marta (n.d.), Audiodeskrypcja w sæ̨tukach plastycznych, http://audiodeskrypcja.pl/ sztukiplastyczne.html [access: 7 February 2017].

Kalbarczyk Marek, Mirowski Janusz (2015), Świat opisywany díwiekeiem, Fundacja Szansa dla Niewidomych, Warszawa.

Muzeum Miasta Łodzi. Udogodnienia, http://dostepne.muzeum-lodz.pl/index.php/udogodnienia [access: 7 February 2017].

Muzeum Sztuki w Lodzi, http://msl.org.pl/ [access: 7 February 2017].

Neves Josélia (2012), Multi-sensory Approaches to (Audio) Describing the Visual Arts, "MonTi. Monografías de Traducción e Interpretación”, no. 4.

Pawłowska Aneta, Wendorff Anna (2016), Ustyszeć obraz — koncepcja audiodeskrypcji Sali Neoplastycznej w Muzeum Sztuki w Lodzi [in:] Dostrzec wiecej. Wybrane zagadnienia wizualizacji danych $w$ badaniach nad dziedzictwem kulturowym, eds J. Kolenda, A. Seidel-Grzesińska, K. Stanicka-Brzezicka, Agencja Wydawnicza ARGI s.c., Wrocław.

Pujol Joaquim, Orero Pilar (2007), Audio Description Precursors: Ekphrasis and Narrators, "Translation Watch Quarterly", vol. 3 (2).

Sławiński Janusz (1998), Ekfraza [in:] Stownik terminów literackich, ed. M. Głowiński, Zakład Narodowy im. Ossolińskich, Wrocław.

Warsz̨at na Zachęe II — Lódź: Muz̨eum Sztuki w Lodẓi (2014), https://www.youtube.com/watch?v=9lhiPHvH6sw [access: 9 February 2017].

Więckowski Robert (2013), Zobaçyć muzeum [in:] ABC Gość niepetnosprawny w muzeum, no. 2, Narodowy Instytut Muzealnictwa i Ochrony Zbiorów, Warszawa.

Więckowski Robert (2014), Audiodeskrypcja piekna, "Przekładaniec", no. 28. 